\title{
MOBILIZAÇÃO DE RESERVAS EM SEMENTES DE Apuleia leiocarpa (Vogel) J.F. Macbr. (GARAPA) DURANTE A EMBEBIÇÃ̃ ${ }^{1}$
}

\author{
Claudia Aparecida Pontes², Eduardo Euclydes de Lima e Borges 3 , Rita de Cassia Gonçalves Borges ${ }^{3} \mathrm{e}$ \\ Carlos Pedro Boechat Soares ${ }^{3}$
}

\begin{abstract}
RESUMO - Quantificou-se a mobilização de reservas no eixo embrionário, nos cotilédones e no tegumento de sementes de Apuleia leiocarpa (garapa), durante a germinação. Os resultados mostram que houve aumento significativo das reservas de amido, ácido esteárico e proteína nos cotilédones durante o processo de embebição. Por outro lado, no embrião houve aumento significativo somente nos teores de manose, enquanto as reservas dos ácidos graxos mirístico, palmítico, esteárico, oléico e linoléico decresceram significativamente. Os teores de manose e galactose aumentaram significativamente no tegumento. Com exceção do ácido láurico, todos os demais não foram detectados após 48 horas de embebição.
\end{abstract}

Palavras-chave: Semente, Apuleia leiocarpa, fisiologia e germinação.

\section{SEED RESERVE MOBILIZATION OF Apuleia leiocarpa (Vogel) J.F. Macbr. (GARAPA) DURING IMBIBITION}

\begin{abstract}
The mobilization of reserves was quantified in the embryonic axis, cotyledons and tegument of seeds of Apuleia leiocarpa (garapa) during imbibition. The results show that there was a significant increase in the contents of starch, estearic acid and protein in the cotyledons during the imbibition process. On the other hand, there was only a significant manose content increase in the embryo while the reserves of fatty acids miristic, palmitic, estearic, oleic and linoleic decreased significantly. Mannose and galactose contents increased significantly in the tegument. Except for the lauric acid, all others were not detected after 48 hours of imbibition.
\end{abstract}

Key words: Seeds, Apuleia leiocarpa, physiology and imbibition.

\section{INTRODUÇÃO}

As reservas de carboidratos, lipídios e proteínas presentes nas sementes são utilizadas pelo embrião como fonte de energia e substrato para estruturas celulares. A utilização de amido ou de açúcares solúveis é variável, dependendo da espécie, podendo ser durante a germinação ou no estádio de plântula. Stone \& Gifford (1999) observaram decréscimo de $80 \%$ dos carboidratos armazenados no megagametófito de sementes de Pinus taeda durante a germinação e no estádio de plântulas. Por outro lado, dados de Suda \& Giorgini (2000) mostram o acúmulo de açúcares solúveis no embrião de Euphorbia heterophylla durante a germinação.

Trabalhando com sementes de Dalbergia miscolobium, Silva et al. (1998) observaram incremento do ácido palmítico e decréscimo do ácido linoléico, nos embriões quiescentes e com 20 a $50 \mathrm{~mm}$ de radícula, respectivamente. Estas observações evidenciam a importância dos

1 Recebido para publicação em 1.10.2001.

Aceito para publicação em 6.11.2002.

Pesquisa financiada pela FAPEMIG.

2 Bolsista de iniciação científica, ${ }^{3}$ Professores do Departamento de Engenharia Florestal da Universidade Federal de Viçosa DEF/UFV, 36571-000 Viçosa-MG. 
lipídios de reserva no eixo embrionário, nos estádios iniciais da germinação. Suda \& Giorgini (2000) constataram redução no teor de lipídio entre 72 e 96 horas de embebição, em embrião de Euphorbia heterophylla.

Em sementes de Qualea grandiflora não foi observada redução no teor de nitrogênio nos cotilédones durante a germinação (Paulilo \& Felippe, 1994). Por outro lado, em sementes de Lupinus albus o grau de degradação protéica foi maior em extratos de cotilédones quiescentes do que em cotilédones in vivo (Duarte et al., 1996). De outra forma, observou-se rápido decréscimo no teor de proteína nos dois primeiros dias de germinação de sementes de Brassica oleracea (Qouta et al., 1991). As diferenças nos resultados entre autores se devem, possivelmente, aos valores obtidos por Suda \& Giorgini (2000), que constataram diferentes padrões de degradação de diferentes frações de proteína em sementes de Euphorbia heterophylla. Enquanto a globulina solúvel em solução salina foi degradada continuamente, a da albumina ocorria somente entre 60 e 84 horas.

Tendo em vista que pouco se conhece a respeito do processo de mobilização de reservas em sementes de espécies florestais nativas durante a germinação, o objetivo deste trabalho foi investigar as alterações de reservas de carboidrato, lipídio e proteína no eixo embrionário, nos cotilédones e no tegumento de sementes de garapa, durante o período pré-germinativo.

\section{MATERIAL E MÉTODOS}

As sementes de Apuleia leiocarpa (Vogel) J.F. Macbr. (garapa) tiveram sua dormência quebrada em escarificador elétrico, por 2 segundos, e em seguida foram colocadas para embeber sobre duas folhas de papel-filtro tipo germitest, em placas de Petri, umedecidas com água destilada, permanecendo em germinador à temperatura de $25^{\circ} \mathrm{C}$ constante, com luz contínua, provida por lâmpadas fluorescente de 40 Watts, tipo luz do dia, por um período de 120 horas. A cada 24 horas as sementes foram retiradas e dissecadas em embrião, cotilédone e tegumento. As amostras foram secas em estufa a $45^{\circ} \mathrm{C}$, por 24 horas, e armazenadas em vidros hermeticamente fechados e mantidos no freezer até a extração e quantificação das reservas.

Para realizar as análises, as amostras de embrião foram maceradas em almofariz de porcelana e as de cotilédones e tegumento foram moídas em moinho elétrico do tipo Willey.

R. Árvore, Viçosa-MG, v.26, n. 5, p. 593-601, 2002
As amostras utilizadas na extração de lipídios foram colocadas em cartuchos de papel-filtro, pesadas e transferidas para conjunto Soxhlet por um período de 24 horas. A extração foi feita a frio, com éter de petróleo (Silva, 1990).

A análise de ácidos graxos foi feita segundo metodologia descrita por Paula (1995). Após a extração, as amostras foram evaporadas até a secura total, sendo ressuspendidas com hexano e injetadas no cromatógrafo.

Os cromatogramas de ácidos graxos foram obtidos em cromatógrafo a gás Shimadzu CG 14-A, equipado com detector de ionização de chama (FID), acoplado a um registrador e integrador C-R6A chromatopac. Utilizou-se coluna capilar Carbowax $50 \mathrm{~m}$ da Shimadzu, de 0,22 mm de sílica fundida, com espessura do filme de $0,25 \mu \mathrm{m}$. O fluxo do gás de arraste $(\mathrm{H} 2)$ foi de $0,5 \mathrm{~kg} / \mathrm{cm}^{2}$. A temperatura do injetor foi de $220{ }^{\circ} \mathrm{C}$, a do detector de $230{ }^{\circ} \mathrm{C}$ e a da coluna de $190{ }^{\circ} \mathrm{C}$ isométrica, durante 60 segundos, seguida de elevação na razão de $2^{\circ} \mathrm{C} / \mathrm{min}$ até atingir a temperatura máxima de $220^{\circ} \mathrm{C}$, permanecendo por 35 minutos. Foram utilizadas três repetições na quantificação de ácidos graxos.

A extração dos açúcares redutores foi feita em banho-maria (Buckeridge \& Dietrich, 1990). Após cada extração a mistura foi centrifugada, retirando-se o sobrenadante, que foi usado na quantificação de açúcares solúveis totais pelo método colorimétrico (Dubois et al., 1956), enquanto os açúcares redutores o foram por cromatografia gasosa.

Após a extração dos açúcares solúveis a amostra foi seca em estufa a $45^{\circ} \mathrm{C}$, por 48 horas, e submetida à digestão com ácido perclórico para quantificação colorimétrica de amido (Passos, 1989).

A extração de galactomanano foi feita conforme Buckeridge \& Dietrich (1990), que consistiu em adicionar água destilada na amostra do tegumento e em mantê-la em banho-maria a $75^{\circ} \mathrm{C}$ por um período de 8 horas. Após a extração, a amostra foi filtrada com três volumes de etanol comercial, permanecendo em repouso no freezer. A quantificação do galactomanano consistiu em digerilo em ácido trifluoracético, e os monossacarídeos liberados foram quantificados por cromatografia gasosa

Os açúcares redutores extraídos diretamente das sementes ou obtidos pela digestão do galactomanano foram transformados em alditol acetato, para quantificação em cromatografia gasosa (Englyst \& Cummings, 
1984). Os cromatogramas foram obtidos com o uso de coluna Shimadzu de $25 \mathrm{~m}$. A temperatura da coluna foi de $220{ }^{\circ} \mathrm{C}$, a do injetor de $250{ }^{\circ} \mathrm{C}$ e a do detector de $275^{\circ} \mathrm{C}$. Aplicou-se injeção de 1,0 $\mu$ l para cada corrida cromatográfica. Foram utilizadas quatro repetições para o açúcar redutor.

A extração de proteína solúvel foi realizada de acordo com a metodologia descrita por Alfenas et al. (1991). A quantificação foi efetuada de acordo com Bradford (1976).

De posse das concentrações de lipídios, açúcares e proteínas presentes no embrião, nos cotilédones e no tegumento das sementes ao longo da embebição, procedeu-se ao ajuste das equações de regressão, pelo método stepwise (Draper \& Smith, 1981), com o objetivo de analisar o comportamento das referidas concentrações em relação ao tempo de germinação. Desta forma, analisando a significância dos coeficientes das equações selecionadas, a 95\% de probabilidade, e os sinais associados aos coeficientes das equações, pode-se concluir a respeito das tendências de aumento ou diminuição das concentrações ao longo do tempo ou pela não-modificação das concentrações, caso os coeficientes das equações fossem não-significativos.

\section{RESULTADOS E DISCUSSÃO}

Os teores médios de amido nos embriões das sementes de garapa (Figura 1a) não diferiram estatisticamente durante o período de embebição, enquanto nos cotilédones (Figura 1b) aumentaram significativamente.

Observa-se que os teores médios de açúcares solúveis do embrião e dos cotilédones não diferiram significativamente durante o período de embebição (Figura 2a e 2b), muito embora haja tendência de mobilização dessas reservas durante o período de embebição. Apesar de ter havido sementes com protrusão de radícula, o que permitiu estabelecer a germinação das sementes de garapa, não houve dependência de carboidratos como fonte de energia ou mesmo para criar estruturas físicas na fase pré-germinativa.

Resultados semelhantes foram observados em sementes de Senna macranthera, cuja germinação ocorreu como conseqüência da expansão celular (Borges et al., 2001). Segundo os autores, os decréscimos nos teores de açúcares solúveis naqueles embriões foram, aparentemente, usados na respiração ou exsudados para o meio durante a fase inicial de embebição. Aparentemente a mobilização dessas reservas ocorre após a protrusão da radícula, como mostrado por Sassaki \& Felippe (1992), com mudas de Dalbergia miscolobium, em que se observou claro aumento nos teores de açúcares solúveis tanto na raiz, quanto na parte aérea, durante o desenvolvimento das mudas. Como ocorreu com sementes de Pinus taeda, os carboidratos solúveis no megagametófito e no eixo embrionário decresceram durante a germinação, vindo a aumentar durante o crescimento da muda (Stone \& Gifford, 1999). De acordo com os autores, o acúmulo de amido ocorreu no megagametófito próximo ao tempo de protrusão da radícula.
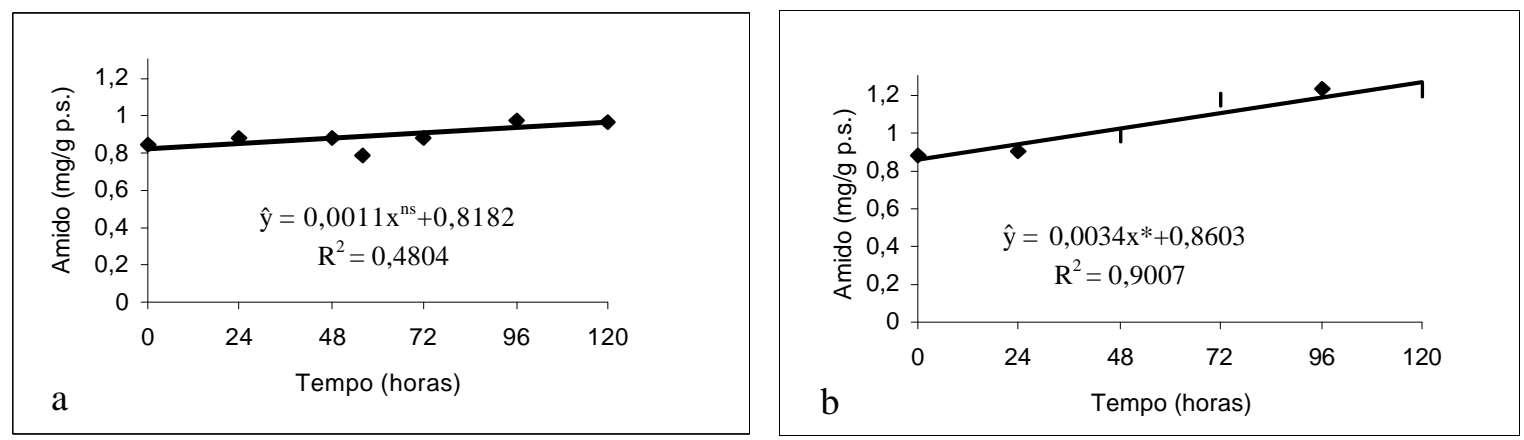

* Valor significativo a $5 \%$ e ns valor não-significativo a $5 \%$, pelo teste $\mathrm{t}$.

* Significant at 5\% and ns not significant at 5\%, by the test.

Figura 1 - Concentrações médias de amido em sementes de Apuleia leiocarpa durante a embebição, em função do tempo. a) embrião e b) cotilédone.

Figure 1 - Average contents of starch during imbibition of Apuleia leiocarpa seeds. a) embryo, and b) cotyledon. 

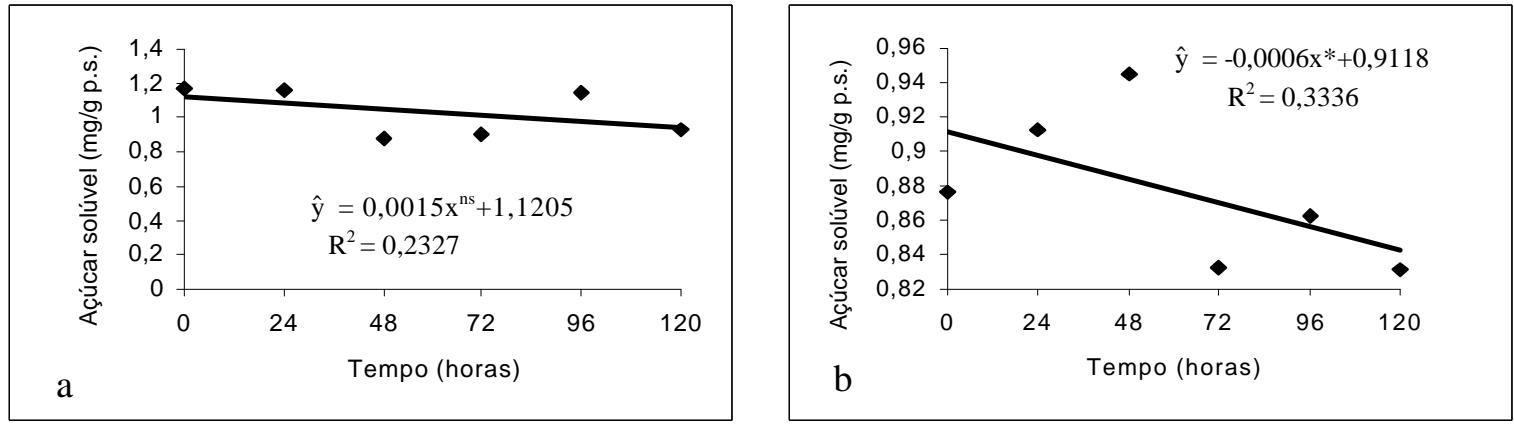

* Valor significativo a $5 \%$ e ns valor não-significativo a $5 \%$, pelo teste $\mathrm{t}$.

* Significant at $5 \%$ and ns not significant at $5 \%$, by the t test.

Figura 2 - Concentrações médias de açúcares solúveis em sementes de Apuleia lei ocarpa durante a embebição. a) embrião e b) cotilédone.

Figure 2 - Average content of soluble sugar in Apuleia leiocarpa seeds during imbibition. a) embryo, b) cotyledon.
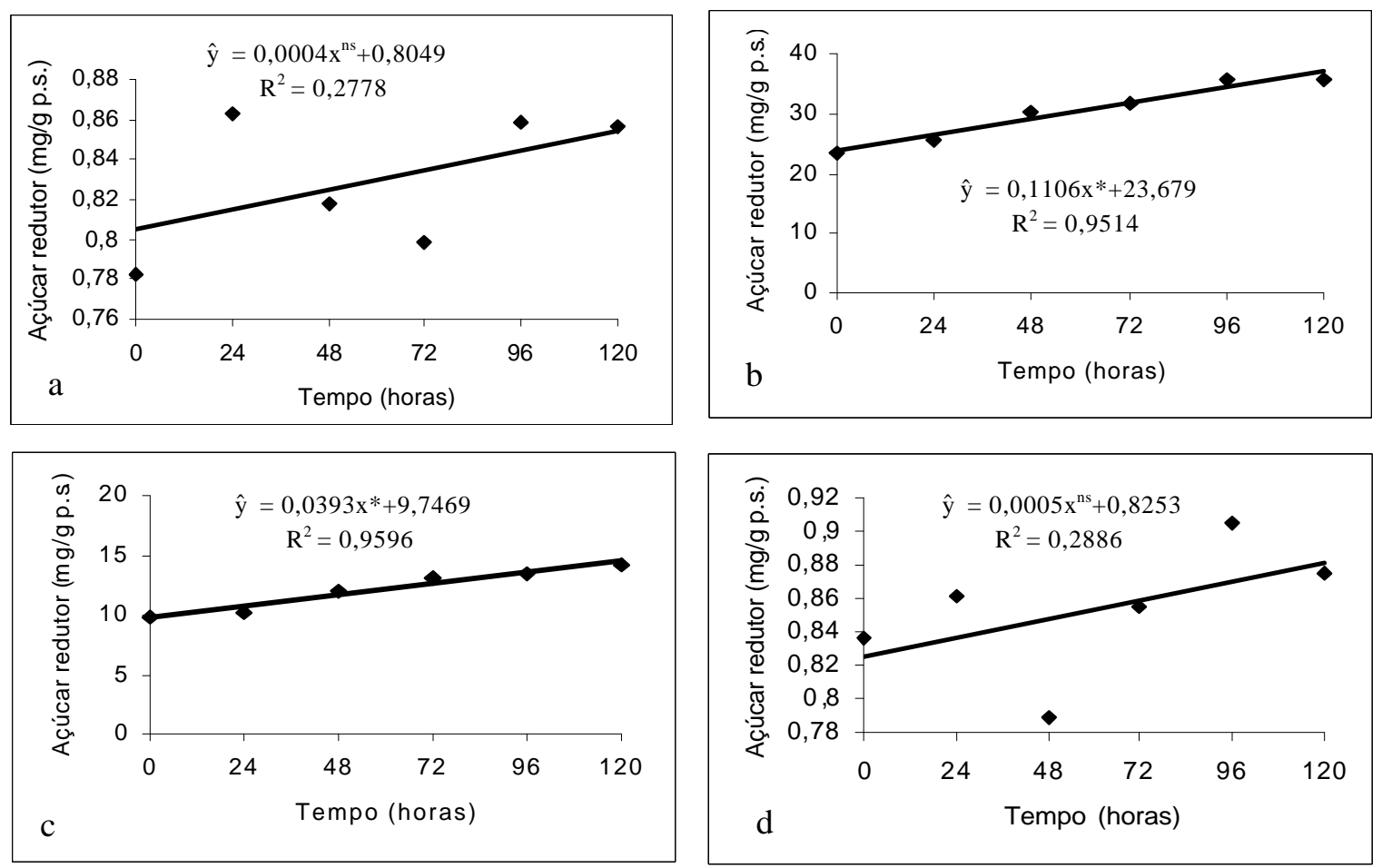

* Valor significativo a $5 \%$ e ns valor não-significativo a $5 \%$, pelo teste t.

* Significant at $5 \%$ and ns not significant at $5 \%$ by the t test.

Figura 3 - Concentrações médias de açúcares redutores em tegumentos de sementes de Apul ei a lei ocarpa durante a embebição. a) arabinose, b) manose, c) galactose e d) xilose.

Figure 3 - Average content of reducing sugars in Apuleia leiocarpa seed coat during seed imbibition. A) arabinose, b) mannose, c) galactose, and d) xilose.

R. Árvore, Viçosa-MG, v.26, n. 5, p. 593-601, 2002 
Detalhando as análises, constata-se que não houve variações significativas nos teores de arabinose e xilose no tegumento, enquanto os de manose e galactose aumentaram significativamente (Figura 3). Pelas altas concentrações iniciais desses dois últimos, conclui-se que as sementes de garapa possuem reservas de galactomanano, depositadas em células junto ao tegumento, que foram transformadas em locais de armazenamento, sem atividades metabólicas, sendo degradadas pelas enzimas hidrolíticas durante a embebição. Desta forma, conclui-se que o aumento verificado se deve à deposição de açúcares provenientes de outros locais da semente, que foram carreados pela água de embebição em direção ao meio externo e ficaram retidos no tegumento.

Os teores de manose aumentaram significativamente no eixo embrionário durante a embebição (Figura 4b) e, de maneira semelhante à verificada nas concentrações dos açúcares do tegumento, somente foram detetados após 72 horas de embebição.

A glicose, por outro lado, apesar do comportamento semelhante ao da manose, não teve diferença significativa durante a embebição (Figura 4a). Os oligossacarídeos da família da rafinose são citados por Guimarães et al. (2001) como utilizados como fonte de energia durante a germinação, o que explicaria os aumentos verificados nos açúcares redutores nas sementes de garapa. Embora não haja diferenças significativas entre teores de açúcares solúveis (Figura 2), percebe-se tendência de queda, o que explicaria, pelo menos parcialmente, os resultados aqui obtidos.

Na Figura 5a, pode-se constatar que somente os teores de ácido láurico presentes nos embriões não diferiram estatisticamente durante a pré-germinação, sendo detectados em maiores concentrações até 48 horas de embebição, com posterior tendência de queda. Todos os demais ácidos graxos detectados no embrião apresentaram variações estatísticas significativas, com consumo desse tipo de reserva. $\mathrm{O}$ ácido oléico (Figura 5e) foi o que apresentou a maior concentração nos embriões, enquanto os ácidos láurico (Figura 5a), palmítico (Figura 5c) e linoléico (Figura 5f) apresentaram as menores. O ácido láurico foi detectado até 120 horas de embebição, enquanto os demais desapareceram em 72 horas, o que indica que a mobilização dos ácidos no embrião é um evento pré-germinativo. Por outro lado, percebe-se que os teores de ácidos graxos nos cotilédones (Figura 6) não tiveram variações significativas, com exceção do ácido esteárico (Figura 6d), cujo valor aumentou significativamente. É possível concluir que as necessidades de substâncias energéticas e estruturais físicas são supridas por lipídios do próprio eixo embrionário, uma vez que não são usadas na síntese de amido (Figura 1) e nem se acumulam no eixo embrionário como açúcares solúveis (Figura 2) ou redutores (Figura 4). Por outro lado, o acúmulo dos ácidos graxos esteáricos permite concluir que há degradação de lipídio e acúmulo de parte de seus produtos, além de possível conversão parcial em amido (Figura 1).
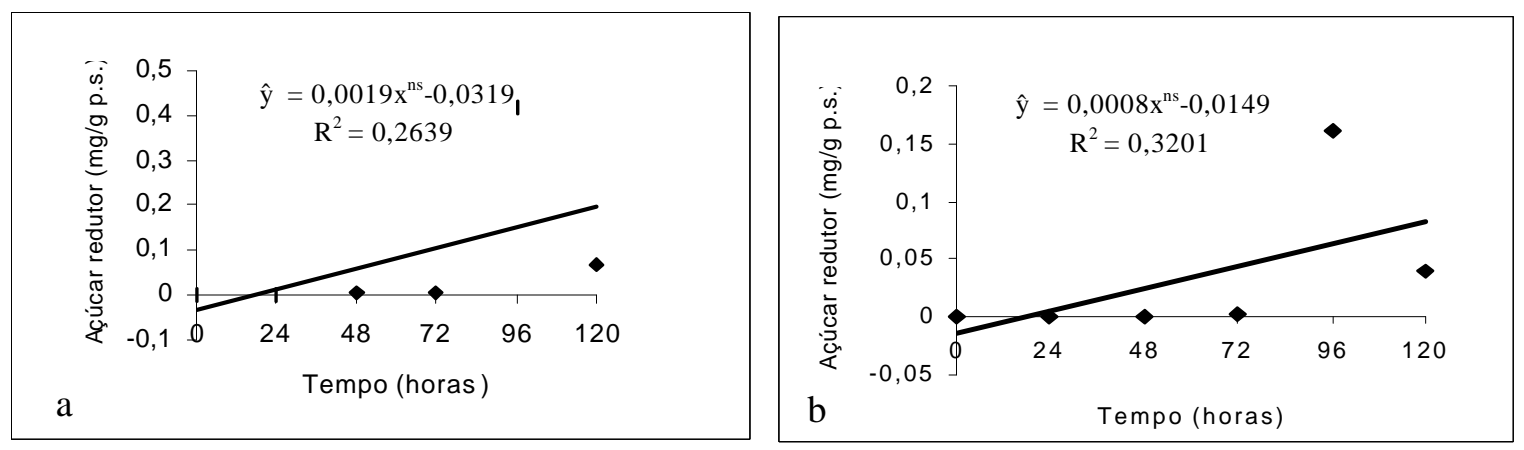

* Valor significativo a 5\% e ns não-significativo a 5\%, pelo teste t.

* Significant at $5 \%$ and ns not significant at $5 \%$ by the $t$ test.

Figura 4 - Concentrações médias de açúcares redutores em embrião de sementes de Apul eia lei ocarpa durante a embebição. a) glicose e b) manose.

Figure 4 - Average content of reducing sugars in Apuleia leiocarpa embryos during imbibition. a) glucose, and b) mannose. 

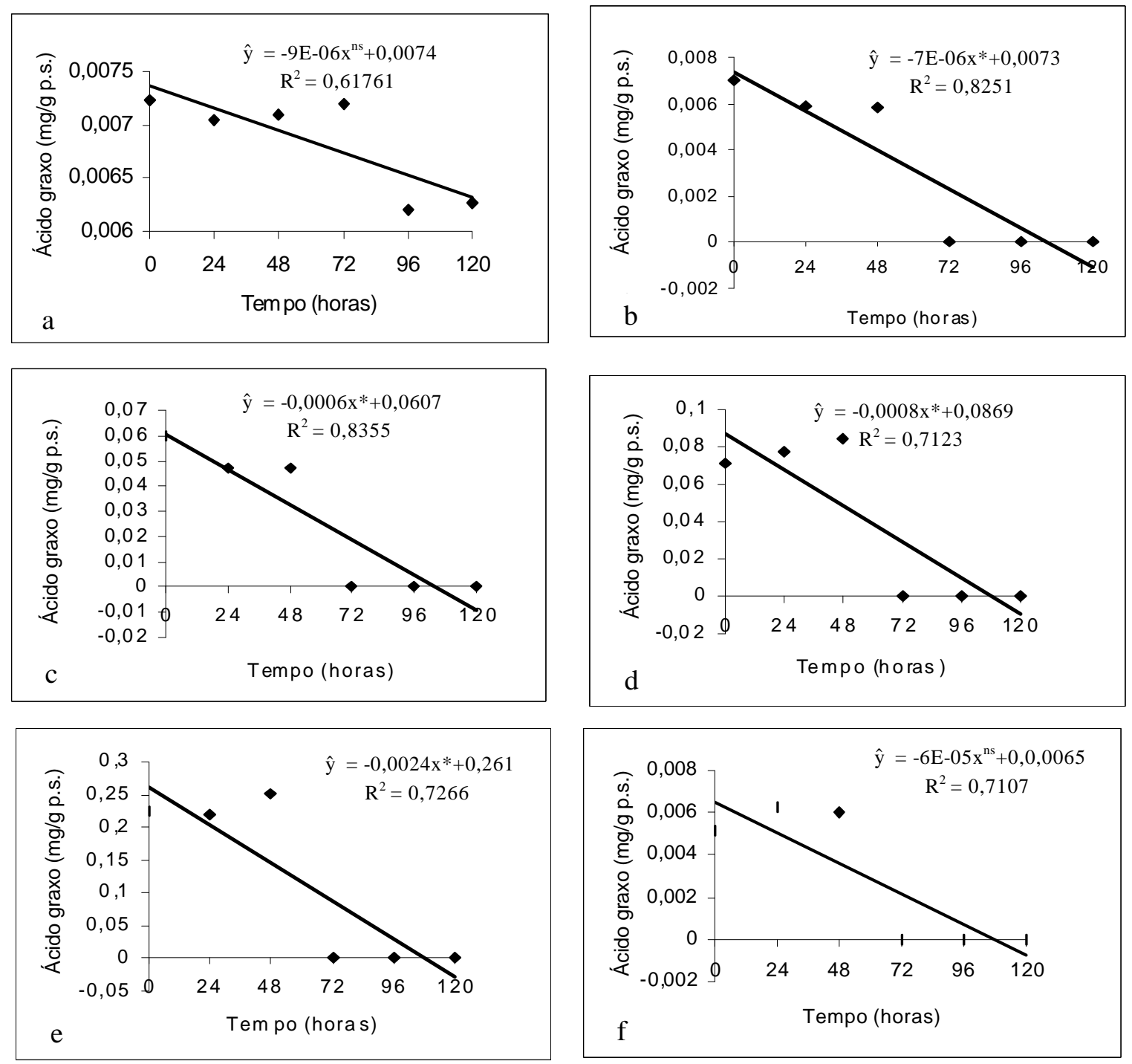

* Valor significativo a $5 \%$ e ns valor não-significativo a $5 \%$, pelo teste $\mathrm{t}$.

* Significant at $5 \%$ and ns not significant at $5 \%$ by the test.

Figura 5 - Concentrações médias de ácidos graxos no embrião de sementes de Apuleia lei ocarpa durante a embebição. a) láurico, b) mirístico, c) palmítico, d) esteárico, e) oléico e f) linoléico.

Figure 5 - Average content of fatty acids in Apuleia leiocarpa embryo during imbibition. a) lauric, b) miristic, c) palmitic, d) stearic, e) ol eic, and f) linol eic.

Em sementes de Pinus edulis a utilização de reservas de lipídios só foi detectada no eixo embrionário e no megagametófito durante 21 dias, com redução de $80 \%$ daquela reserva (Hammer \& Murphy, 1994). Por outro lado, Silva et al. (1998) verificaram que os valores de lipídios não alteraram significativamente no eixo embrionário até a protrusão da radícula, enquanto nos cotilédones ocorreu decréscimo significativo quando o eixo embrionário possuía 20 a $50 \mathrm{~mm}$. Os ácidos linoléico, esteárico, oléico e palmítico foram também detectados nos cotilédones em todos os estádios, da mesma forma que no presente trabalho. Trabalhando com sementes de 
Dalbergia nigra osmocondicionadas, Borges et al. (2000) observaram redução dos ácidos graxos palmítico, oléico, linoléico e esteárico em relação àquelas sem prétratamento. Qouta et al. (1991) verificaram mobilização de reservas em sementes de Brassica oleracea somente após dois dias do início da embebição.
Os teores médios de proteínas dos embriões e cotilédones estão apresentados na Figura 7a e 7b. Enquanto no embrião os valores não diferiram estatisticamente durante o período de embebição, houve significativo acúmulo nos cotilédones no mesmo período.
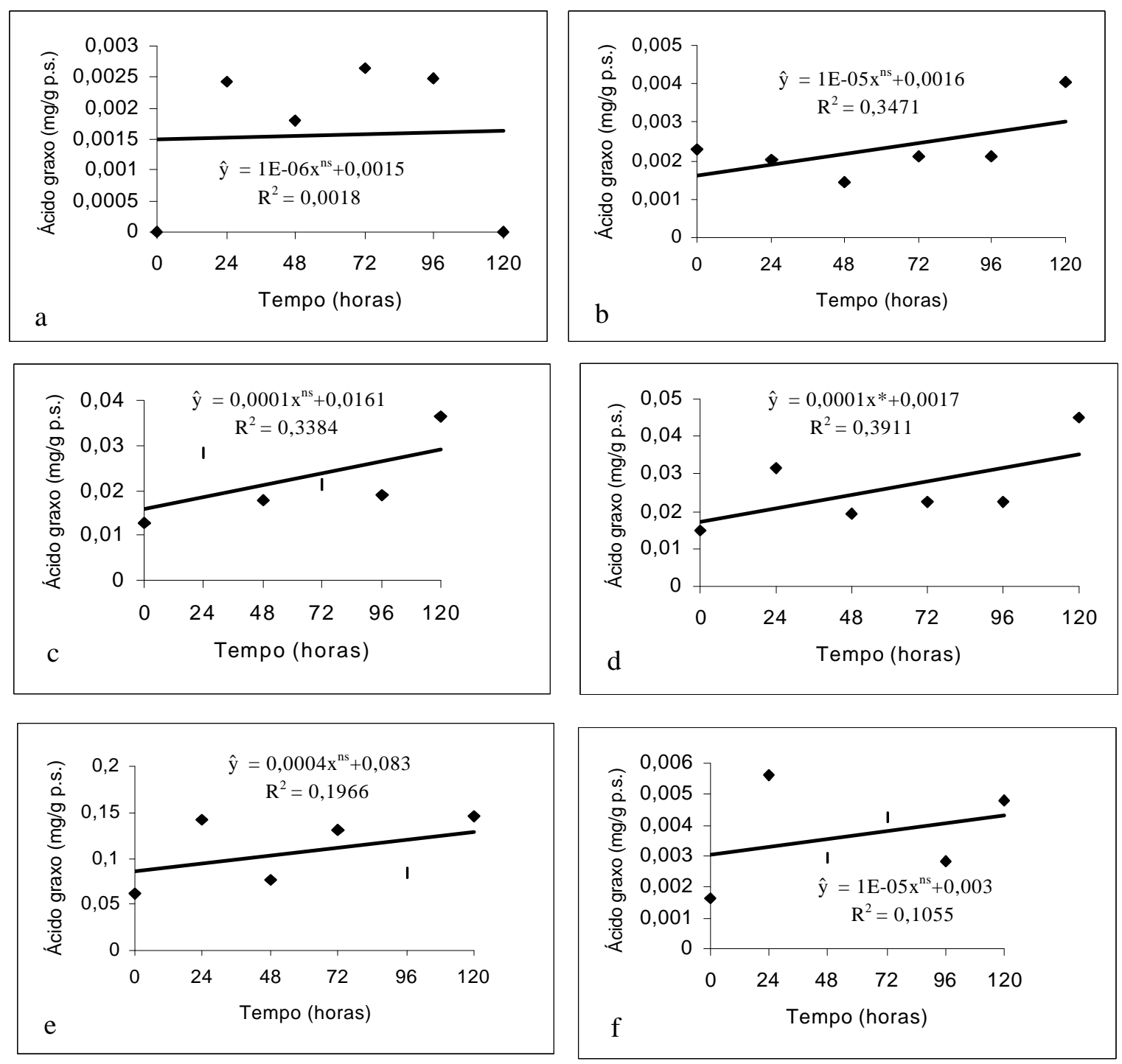

* Valor significativo a $5 \%$ e ns valor não-significativo a 5\%, pelo teste t.

* Significant at $5 \%$ and ns not significant at $5 \%$ by the t test.

Figura 6 - Concentrações médias de ácidos graxos em cotilédones de sementes de Apuleia lei ocarpa durante a embebição. a) láurico, b) mirísticos, c) palmítico, d) esteárico, e) oléico e f) linoléico.

Figure 6 - Average contents of fatty acids for cotyledons of Apuleia leiocarpa seeds during imbibition. a) lauric, b) mi ristic, c) palmitic, d) stearic, e) ol eic, and f) linoleic. 

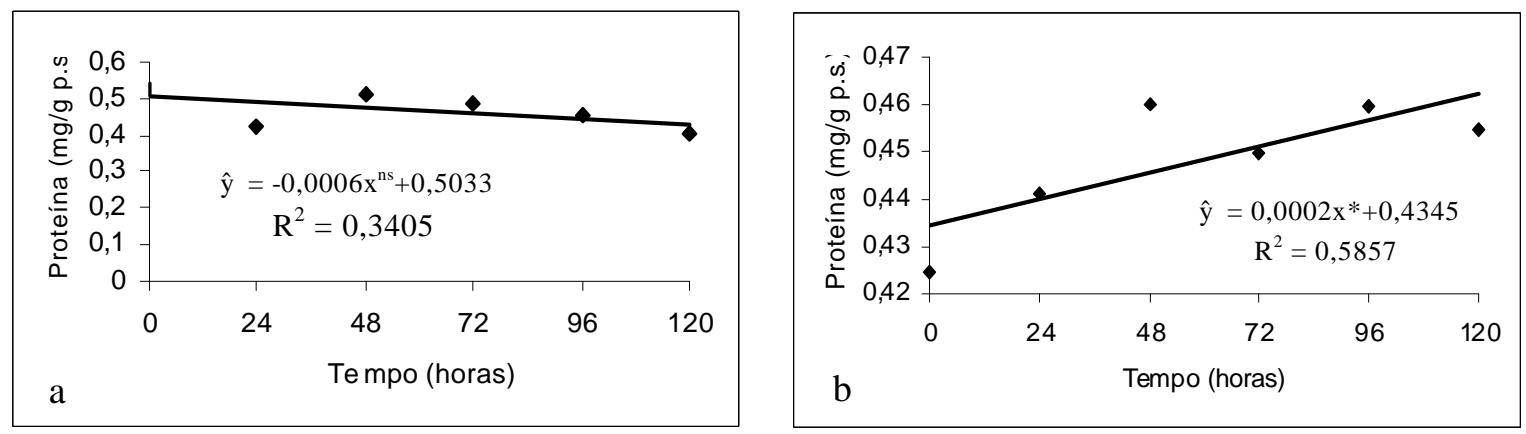

* Valor significativo a $5 \%$ e ns valor não-significativo a $5 \%$, pelo teste t.

* Significant at $5 \%$ and $n s$ not significant at $5 \%$ by the $t$ test.

Figura 7 - Concentrações médias de proteína em sementes de Apuleia leiocarpa durante a embebição. a) embrião e b) cotilédone.

Figure 7 - Average content of protein in Apuleia leiocarpa seeds during imbibition.

a) embryo, b) cotyledons.

Tais resultados diferem dos observados por Paulilo \& Felippe (1994), que não verificaram redução no teor de nitrogênio nos cotilédones de sementes de Qualea grandiflora, durante as nove semanas de teste. Por outro lado, resultados obtidos por Suda \& Giorgini (2000) evidenciam a translocação de aminoácidos provenientes da degradação da proteína para o embrião.

Tendo em vista os resultados obtidos, concluiu-se que a reserva de lipídio no embrião é a única a ser utilizada durante a fase pré-germinativa, enquanto as demais permanecem constantes em seus teores. Por outro lado, os cotilédones acumulam reservas que seriam usadas na fase de plântula.

\section{REFERÊNCIAS BIBLIOGRÁFICAS}

ALFENAS, A. C. et al. Eletroforese de proteínas e isoenzimas de fungos e essências florestais. Viçosa: Sociedade de Investigações Florestais, 1991. 242 p.

BORGES, E. E. L.; BORGES, R. C. G.; BUCKERIDGE, M. S. Alterações nas composições de carboidratos e de ácidos graxos em sementes de jacaradá-da-bahia osmocondicionadas. Revista Brasileira de Fisiologia Vegetal, v. 12, n. 1, p. 10-16, 2000.

BORGES, E. E. L. et al. Crescimento e mobilização de carboidrato em embrião de sementes de fedegoso (Senna macranthera Irwin et Barneby) durante a germinação.

Revista CERNE, v. 7, n. 1, 2001.

BRADFORD, M. M. A rapid and sensitive method for the quantification of microgram quantities of proteins utilizing the principle-dye binding. Analytical Biochemistry, v. 72, p. 248-254, 1976.

R. Árvore, Viçosa-MG, v.26, n. 5, p. 593-601, 2002
BUCKERIDGE, M. S.; DIETRICH, S. M. C. Galactomanans from Brazilian legume seeds. Revista Brasileira Botânica, v. 13, p. 109-112, 1990.

DRAPER, W. R.; SMITH, H. Applied regression analysis. New York: John Willey \&Sons, 1981. 709 p.

DUARTE, I.; CÂNDIDO, P. P. R.; DUQUE-MAGALHÃES, M. C. Proteolysis in the quiescent seed. Physiologia Plantarum, v. 96, p. 519-525, 1996.

DUBOIS, M. et al. Colorimetric method for determination of sugars and related substances. Annalical Chemestry, v. 28, p. 350-356, 1956.

ENGLYST, H. N.; CUMMINGS, J. H. Simplified method for the measurement of total non-starch polysaccharides by gas-liquid chromatograph of constituent sugars as alditol acetates. Analyst, v. 109, p. 973-942, 1984.

GUIMARÃES, V. M. et al. Characterization of $\alpha$ galactosidases from germinating soybean seed and their use for hydrolysis of oligosaccharides. Phytochemistry, v. 58, p. 67-73, 2001.

HAMMER, M. F.; MURPHY, J. B. Lipase activity and in vivo triacylglycerol utilizationduring Pinus edulis seed germination. Plant Physiology of Biochemistry, v. 32, n. 6, p. 861-867, 1994.

PASSOS, L. P. Growth and water status responses of mung bean (Vigna mungo L.)and other dicot species to osmotic stress. Tucson: University of Arizona, 1989. 108 p. Thesis (Ph.D.) - University of Arizona, 1989. 
PAULA, V. F. Estudo químico e da interação inseto-planta em Ochroma lagopus Swartz. Viçosa-MG: UFV, 1995. 132 p. Dissertação (Mestrado em Agroquímica) UniversidadeFederal de Viçosa, 1995.

PAULILO, M. T. S.; FELIPPE,G. M. Contribuição dos cotilédones e participação de matéria durante o cescimento inicial de Qualea grandiflora Mart. (Vochysiaceae). Revista Brasileira de Botânica, v. 17, n. 2, p. 87-91, 1994.

QOUTA, L. A. et al. Changes in seed reserves and cell-wall composition of component organs during germination of cabbage (Brassica oleracea) seeds. Journal Plant Physiology, v. 138, n. 6, p. 700-707, 1991.

SASSAKI, R.. M.; FELIPPE, G. M. Remoção dos cotilédones e desenvolvimento inicial de Dalbergia miscolobium. Revista Brasileira de Botânica, v. 15, n. 1, p. 5-16, 1992.
SILVA, D. J. Análise de alimentos (métodos químicos e biológicos). Viçosa-MG: UFV, Imprensa Universitária, 1990. 165 p.

SILVA, T. R. G.; CORTELAZZO, L. A.; DIETRICH, S. M. C. Variations in storage compounds during germination and early plantlet growth of Dalbergia miscolobium. Revista Brasileira de Fisiologia Vegetal, v. 10, n. 2, p. 119-124, 1998.

STONE, S. L.; GIFFORD, D. J. Structural and biochemical changes in Loblolly pine (Pinus taeda) seeds during germination and early seedling growth. 1l. Storage triacylglicerols and carbohydrates. International Journal Plant Science, v. 160, n. 4, p. 663-671, 1999.

SUDA, N. K. C.; GIORGINI, J. F. Seed reserve composition and mobilization during germination and initial seedling development of Euphorbia heterophylla. Revista Brasileira de Fisiologia Vegetal, v. 12, n. 3, p. 226-245, 2000. 